\title{
Strains of Achromobacter xylosoxidans from clinical material
}

\author{
B. HOLMES, J. J. S. SNELL, AND S. P. LAPAGE
}

From the National Collection of Type Cultures, Central Public Health Laboratory, Colindale, London NW9 5 HT

SUMMARY Eleven strains of Achromobacter xylosoxidans have been received from among 1106 strains of Gram-negative, non-fermentative bacteria submitted to the National Collection of Type Cultures for computer-assisted identification since 1 January 1972. The strains showed resistance to a wide range of antimicrobial agents and five of the isolates possibly played a pathogenic role. The biochemical characteristics of these 11 strains were compared with those of three culture collection strains.

Achromobacter xylosoxidans is a new species recently proposed by Yabuuchi and Ohyama (1971) for seven strains of Gram-negative, non-fermentative bacteria which have peritrichous flagellation and produce acid from xylose. These strains were isolated from purulent ear discharges of seven patients with chronic otitis media. More recently Yabuuchi et al. (1974) described in detail 55 strains of $A$. xylosoxidans isolated from a wide range of clinical material. They described biochemical characters, sensitivity to antibiotics, and DNA base composition. Among their 55 strains of $A$. xylosoxidans were 10 strains which had been designated as groups IIIa and IIIb by King (1964).

We report here the results of biochemical and antibiotic sensitivity tests of 14 strains of $A$. xylosoxidans.

\section{Material and methods}

\section{ORGANISMS}

Fourteen strains of $A$. xylosoxidans were examined (Table 1). They comprised 11 field strains (10 of which have been isolated from clinical material in the United Kingdom) sent to the National Collection of Type Cultures for computer-assisted identification and three reference strains maintained in the National Collection of Type Cultures (NCTC), Colindale. All three reference strains were included in the original description of $\boldsymbol{A}$. xylosoxidans given by Yabuuchi and Ohyama (1971), and one of these three strains (NCTC 10807) is the type strain of the species.

Received for publication 15 December 1976
CLINICAL DETAILS OF FIELD STRAINS

Strain 1 was isolated in scanty growth from a bottle of blood during routine screening of blood for infection before transfusion. The blood was found to be infected, so was not given to a patient.

Strain 2 was isolated from a blood culture of a man with septicaemia and acute renal failure. The patient, who was treated with gentamicin for three weeks, died nine days after the blood culture was taken. Further details were not available.

Strain 3 was recovered as a scanty growth from a catheter specimen of the urine of a man on only one occasion. The urine never contained white cells and the organism did not appear to cause infection.

Strain 4 was isolated from the sputum of a 40 -yearold woman. The patient had suffered from chronic bronchitis for many years. Sputum examinations during this period had generally shown pneumococci and haemophili. The strain of $A$. xylosoxidans was isolated on only one occasion, when the patient was on long-term steroid inhalation therapy.

Strain 5 came from a wound swab taken from a 38-year-old woman who had undergone mastectomy for carcinoma of the breast about nine months previously. She had already received steroid, hormonal, chemo-, and radiotherapy. About three months before the swab was taken she had immunotherapy that included administration of BCG, and acid-fast bacilli were seen in films from the swab in addition to growth of the isolate of $A$. xylosoxidans.

Strain 6 represented a series of isolates grown from blood culture bottles and were considered to be contaminants. Before taking blood from a patient the skin was disinfected with a chlorhexidine 
Table 1 Strains of A. xylosoxidans examined

\begin{tabular}{|c|c|c|c|}
\hline Strain No. & $\begin{array}{l}\text { Original strain } \\
\text { designation }\end{array}$ & Received from: & Source \\
\hline \multicolumn{4}{|l|}{ Field strains } \\
\hline 1 & CL333/72 & C. H. L. Howells, Cardiff & Transfusion blood \\
\hline 2 & CL356/72 & R. C. B. Slack, London & Blood culture \\
\hline 3 & CL156/73 & I. Phillips, London & Urine \\
\hline 4 & CL318/73 & R. Howden, Sheffield & Sputum \\
\hline 5 & CL116/74 & R. Postlethwaite, Aberdeen & Wound swab \\
\hline 6 & CL600/74 & I. Phillips, London* & Blood \\
\hline 7 & CL275/75 & S. D. Graham, Manchester & Swimming pool \\
\hline 8 & CL356/75 & A. J. Howard, London & Orbit swab \\
\hline 9 & CL434/75 & C. Aubrey, London & Bile and blood culture \\
\hline 10 & CL527/75† & M. P. Jevons, London & $0.5 \%$ chlorhexidine \\
\hline 11 & CL646/75 & R. M. Perinpanayagam, London & Wound swab \\
\hline \multirow{4}{*}{$\begin{array}{l}\text { Culture collection strains } \\
\text { NCTC } \ddagger 10807 \text { (type strain) } \\
\text { NCTC } 10808 \\
\text { NCTC } 10809\end{array}$} & \multirow{4}{*}{$\begin{array}{l}\mathbf{K M} \| 543 \\
\mathbf{K M} 563 \\
\text { KM } 583\end{array}$} & \multirow[b]{2}{*}{ E. Yabuuchi, Osaka } & \multirow[b]{2}{*}{ Ear discharge } \\
\hline & & & \\
\hline & & ", & , \\
\hline & & ", & ", \\
\hline
\end{tabular}

* Strain sent to I. Phillips by O. A. Okubadejo, Portsmouth.

+Four additional isolates of this strain also examined.

$\ddagger$ NCTC $=$ National Collection of Type Cultures.

|| KM = Kansai Medical School Culture Collection.

gluconate-based disinfectant delivered as an aerosol from a pressurised canister (Hibispray). The strain of $A$. xylosoxidans was isolated from the aerosolised disinfectant and from around the nozzle of the canister but did not appear to be within the canister. How the organism colonised the canister nozzle could not be explained.

Strain 7 was found growing as a slime in an indoor swimming pool in Germany. The slime was found only on the PVC liner which formed the shell of the pool, and it was suggested that the organism might be utilising chemicals (plasticisers, etc) that had exuded from the liner itself. This point was never proved one way or the other. Between five and 10 people used the pool each day and the water was kept at a temperature of $25-28^{\circ} \mathrm{C}$. No cases of infection were reported.

Strain 8 was isolated from the infected orbit of a 36-year-old Iraqi soldier who had lost an eye due to a shrapnel wound about a year before and subsequently had several plastic operations to reconstruct the orbit. The wound became infected in Iraq about three months before admission to hospital in England and produced small amounts of pus. On three separate occasions during the month after admission swabs from the orbit produced a heavy growth of the organism.

Strain 9 was found in both the blood and bile of a 61-year-old man admitted to hospital in June 1975. He presented with a history of colicky epigastric pain radiating to the right shoulder for one month. He also became distended and had flatulence. He was jaundiced. He first noted this two weeks before admission, when his urine had become dark and his stools pale. Endoscopic retrograde cannulation of the pancreatic duct showed an obstruction $1 \frac{1}{2}$ inches $(3.7 \mathrm{~cm})$ from the ampulla of Vater. The patient became progressively more jaundiced. At operation to relieve the obstruction the liver was seen to be involved by adenocarcinoma. The primary site was not identified. Postoperatively his jaundice faded but his intestinal ileus was rather prolonged. He also had a septicaemia, treated successfully with intravenous co-trimoxazole, caused by an isolate of $A$. xylosoxidans identical with the organism recovered from his bile. He became anaemic and was transfused two units of packed cells. He was discharged in July 1975 fully mobile and on a normal diet.

Strain 10 was isolated from a solution containing $0.5 \%$ chlorhexidine during routine 'in-use' testing of disinfectants in the hospital. The solution was probably infected by the distilled water used for diluting the chlorhexidine. Since the distilled water tank was cleaned the organism has not keen isolated again. No infections due to it were reported. Four additional cultures were later sent from the same hospital for examination; two of them came from two different ward stocks of chlorhexidine $(0.5 \% \mathrm{v} / \mathrm{v}$ in water), one came from chlorhexidine $(0.5 \% \mathrm{v} / \mathrm{v}$ in water) in the casualty department, and the fourth was from the distilled water tank containing the water used for diluting the chlorhexidine. We considered these five organisms to represent different isolates of the same strain since they showed identical results in 65 of the 68 biochemical tests performed, differing from each other only in motility and acid 
production from arabinose and fructose. All five isolates failed to grow at $37^{\circ} \mathrm{C}$, produced acid from mannitol (the only ones in our series to do so), and were identical in their resistance to 13 antimicrobial agents.

Strain 11 was grown from a swab of a superficial wound on the left leg of a 73-year-old man; the injury was sustained by a fall in a drain at his home. The wound healed readily with saline dressings and the patient recovered fully.

\section{BACTERIOLOGICAL STUDIES}

The 11 field strains were compared with the three NCTC reference strains, including the type strain NCTC 10807 (Table 1), in a wide range of biochemical tests (Table 2). Most tests were incubated at $37^{\circ} \mathrm{C}$ except those of the several isolates of strain 10 , which failed to grow at $37^{\circ} \mathrm{C}$ and were incubated at room temperature $\left(18-22^{\circ} \mathrm{C}\right)$. The methods employed were those used by Holmes et al. (1975).

The sensitivity to antibiotics (concentrations are given in Table 3) was determined on Oxoid Diag- nostic Sensitivity Test (DST) agar containing $0 \cdot 25 \%$ (v/v) lysed horse blood. The following antibiotics were tested by incorporation of the antibiotic in paper strips (Anderson and Threlfall, 1974): amoxicillin, ampicillin, carbenicillin, cephalexin, chloramphenicol, colistin, gentamicin, kanamycin, streptomycin, and tetracycline. Sensitivity was determined by the use of commercially prepared discs to co-trimoxazole (Oxoid Ltd, London) and separately to its two components trimethoprim and sulphamethoxazole and also to nalidixic acid (these last three antibiotics all from Mast Laboratories Ltd, Liverpool). Polymyxin B was incorporated in the DST agar. The methods used give a measure only of gross sensitivity or resistance of an organism to a particular antibiotic. Strains were judged to be resistant if their growth was clearly less inhibited than that of a strain of Escherichia coli (K12 F-prototrophic (Smith et al., 1973)) which was used as a sensitive control.

Discs containing the vibriostatic agent $0 / 129$ (2,4-diamino-6,7-di-iso-propyl pteridine phosphate;

Table 2 Biochemical characters of A. xylosoxidans

\begin{tabular}{|c|c|c|c|}
\hline \multicolumn{4}{|l|}{ All strains positive in: } \\
\hline $\begin{array}{l}\text { Acid from ASS* xylose } \\
\text { Alkali production on Christensen's } \\
\text { citrate } \\
\text { Catalase production }\end{array}$ & $\begin{array}{l}\text { Growth at room temperature } \\
\text { Growth on cetrimide } \\
\text { Growth on MacConkey's agar }\end{array}$ & $\begin{array}{l}\text { Growth on } \beta \text {-hydroxybutyrate } \\
\text { Motility } \dagger \\
\text { Nitrate reduction }\end{array}$ & $\begin{array}{l}\text { Oxidase production } \\
\text { Poly- } \beta \text {-hydroxybutyrate inclusion } \\
\text { granules } \\
\text { Tyrosine hydrolysis }\end{array}$ \\
\hline \multicolumn{4}{|l|}{ All strains negative in: } \\
\hline $\begin{array}{l}\text { Acid from PWS } \ddagger \text { glucose } \\
\text { Acid from glucose } 10 \mathrm{~g} / 100 \mathrm{ml} \\
\text { Acid from lactose } 10 \mathrm{~g} / 100 \mathrm{ml} \\
\text { Acid from ASS adonitol } \\
\text { Acid from ASS arabinose } \dagger \\
\text { Acid from ASS callobiose } \\
\text { Acid from ASS dulcitol } \\
\text { Acid from ASS fructose } \dagger \\
\text { Acid from ASS glycerol } \\
\text { Acid from ASS inositol } \\
\text { Acid from ASS lactose }\end{array}$ & $\begin{array}{l}\text { Acid from ASS maltose } \\
\text { Acid from ASS raftinose } \\
\text { Acid from ASS rhamnose } \\
\text { Acid from ASS salicin } \\
\text { Acid from ASS sorbitol } \\
\text { Acid from ASS sucrose } \\
\text { Acid from ASS trehalose } \\
\text { Aesculin hydrolysis } \\
\text { Arginine desimidase } \\
\text { Arginine dihydrolase } \\
\text { Casein digestion }\end{array}$ & $\begin{array}{l}\text { Deoxyribonuclease production } \\
\text { Fluorescence on King's B medium } \\
\text { Gas from PWS glucose } \\
\text { Gelatinase production } \| \\
\text { Gluconate oxidation } \\
\text { Growth at } 5^{\circ} \mathrm{C} \\
\text { Hydrogen-sulphide production } \S \\
\text { Indole production } \\
\text { Lysine decarboxylase } \\
\text { Malonate utilisation } \\
\text { Opalescence on LV agar }\end{array}$ & $\begin{array}{l}\text { Ornithine decarboxylase } \\
\text { Phenylalanine deamination } \\
\text { Pigment production } \\
\text { Pigment production on tyrosine } \\
\text { Reduction of selenite } 0.4 \mathrm{~g} / 100 \mathrm{~m} \\
\text { Starch hydrolysis } \\
\text { Tween } 20 \text { hydrolysis } \\
\text { Tween } 80 \text { hydrolysis } \\
\text { Urease production } \\
\beta-\text { Galactosidase production } \\
\text { (ONPG) } \\
\text { 3-Ketolactose production }\end{array}$ \\
\hline Strains differ in: & Positive & Strains giv & ing the less common result \\
\hline $\begin{array}{l}\text { Acid from ASS glucose } \\
\text { Acid from ASS ethanol } \\
\text { Acid from ASS mannitol } \\
\text { Growth at } 37^{\circ} \mathrm{C} \\
\text { Growth at } 42^{\circ} \mathrm{C} \\
\text { Growth on Simmons' citrate } \\
\text { KCN tol zrance } \\
\text { Nitrite reduction }\end{array}$ & $\begin{array}{r}13 \\
8 \\
1 \\
13 \\
9 \\
12 \\
12 \\
9\end{array}$ & $\begin{array}{l}\text { NCTC } 10 \\
1,2,6,7 \text {, } \\
10 \\
10 \\
1,2,6,10 \\
7 \text { and NC } \\
2,10 \\
1,2,5,6\end{array}$ & $\begin{array}{l}808 \\
10 \text { and NCTC } 10808 \\
11 \\
\text { TC } 108 C 8 \\
7\end{array}$ \\
\hline Hugh and Leifson O-F test & $\begin{array}{l}\text { Alkaline } \\
8\end{array}$ & $\begin{array}{l}\text { Negative } \\
6\end{array}$ & Id NCTC 10807, 10808, 10809 \\
\hline
\end{tabular}

*ASS = ammonium salt sugar.

†Two isolates of strain 10 were non-motile and produced acid from both arabinose and fructose.

‡PWS = peptone water sugar.

\|By both gelatin stab and plate methods.

$\S$ By both lead acetate paper and triple sugar iron agar methods. 
Table 3 Sensitivity of A. xylosoxidans to antimicrobial agents

All strains sensitive to:

Carbenicillin (200 $\mu \mathrm{g} / \mathrm{strip}) \quad$ Colistin $(1000 \mu \mathrm{g} / \mathrm{strip})$

All strains resistant to:

Amoxicillin (200 $\mu \mathrm{g} /$ strip)

Cephalexin (100 $\mu \mathrm{g} / \mathrm{strip})$

0/129*

\begin{tabular}{lccl}
\hline Strains differ in: & Sensitive & Resistant & Strains giving the less common result \\
\hline Ampicillin $(200 \mu \mathrm{g} / \mathrm{strip})$ & 11 & 3 & $3,9,10$ \\
Chloramphenicol $(60 \mu \mathrm{g} / \mathrm{strip})$ & 4 & 10 & $1,2,7,9$ \\
Gentamicin $(60 \mu \mathrm{g} / \mathrm{str} / \mathrm{p})$ & 3 & 11 & $2,7,10$ \\
Kanamycin $(1000 \mu \mathrm{g} / \mathrm{strip})$ & 9 & 5 & 6,8 and $\mathrm{NCTC} 10807,10808,10809$ \\
Streptomycin $(500 \mu \mathrm{g} / \mathrm{strip})$ & 4 & 10 & $1,2,7,10$ \\
Tetracycline $(500 \mu \mathrm{g} / \mathrm{strip})$ & 1 & 13 & 7 \\
Co-trimoxazole $(25 \mu \mathrm{g} / \mathrm{disc})$ & $11 \dagger$ & 9 & 10 and NCTC 10807,10808 \\
Nalidixic acid $(30 \mu \mathrm{g} / \mathrm{disc})$ & 5 & 2 & 6,10 \\
Polymyxin B $(300 \mathrm{IU} / \mathrm{ml})$ & $12 \ddagger$ & & $11,9,11$ \\
\hline
\end{tabular}

*Discs prepared from solution containing $1 \mu \mathrm{g} / \mathrm{ml}$.

†All 14 strains were resistant to the trimethoprim component $(2.5 \mu \mathrm{g} / \mathrm{disc})$ of co-trimoxazole; 11 strains were sensitive to only the sulphamethoxazole component $(50 \mu \mathrm{g} / \mathrm{disc})$ of co-trimoxazole but in each of these 11 strains the two components of co-trimoxazole acted synergistically. $\ddagger$ These strains also sensitive to $100 \mathrm{IU} / \mathrm{ml}$.

BDH Ltd, Poole) were prepared from an aqueous solution of the compound.

\section{DNA BASE COMPOSITIONS}

DNA was extracted by the method of Marmur (1961) and further purified by treatment with protease and phenol as described by Brenner et al. (1969). The Tm determinations were made in $1 / 10$ strength standard saline citrate buffer $(0 \cdot 1$ SSC) in a Pye Unicam SP 1800 spectrophotometer equipped with an electrically heated cell holder and a temperature programmer. The temperature of the DNA was raised at $0.25^{\circ} \mathrm{C} /$ min and absorbance recorded on a Pye Unicam AR 25 series linear strip chart recorder. The temperature of the DNA solution was measured at $0.5^{\circ} \mathrm{C}$ intervals with a thermistor bead inserted in the sample cuvette connected to a temperature reading meter. The thermistor bead and meter were calibrated against a thermometer calibrated at the National Physical Laboratories by immersion of the bead and thermometer in an oil bath to a depth of $8 \mathrm{~cm}$.

The equation used to relate melting temperature (Tm) to DNA base compositions expressed as the percentage of guanine and cytosine/total bases present (\%GC) was that of Mandel et al. (1970):

(1) $\% \mathrm{GC}_{\text {unknown }}=\% \mathrm{GC}$ reference strain + [slope of equation $\times\left(\right.$ T $\left.\left.m_{\text {unknown }}-\mathrm{T} m_{\text {reference strain }}\right)\right]$.

The slope of the equation was derived from the general equation of Owen et al. (1969), which for $0 \cdot 1 \mathrm{SSC}$ gives a slope of $2 \cdot 08$. The average $\mathrm{T} m$ from several determinations of the reference DNA extracted from $E$. coli $\mathrm{B}(\% \mathrm{GC}=50.9)$ was $75 \cdot 2^{\circ} \mathrm{C}$.
Substitution of values for the slope of the equation and $\mathrm{T} m$ of the reference strain in equation 1 gives:

(2) $\% \mathrm{GC}=50 \cdot 9+[2.08 \times(\mathrm{Tm}-75 \cdot 2)]$.

\section{Results}

The organisms were Gram-negative rods producing non-pigmented colonies on nutrient agar. The biochemical test results are shown in Table 2 and arranged by tests in which all strains gave a positive or negative result and by tests in which the strains differed. Sensitivities to antimicrobial agents are shown in Table 3. Although giving negative results for most of the biochemical characters tested (Table 2) the organisms have several distinguishing characteristics by which they may be recognised. All the isolates had peritrichous flagella (Figure). In our ammonium salt sugar medium with bromothymol blue indicator they always produced acid from xylose, generally also from glucose (13/14 strains), and sometimes from ethanol (8/14 strains), although the strains gave a negative or alkaline reaction in Hugh and Leifson's glucose O-F medium. All the isolates reduced nitrate and produced inclusion granules after growth on $\beta$-hydroxybutyrate. The majority of the strains (12/14) grew in KCN medium.

All the isolates grew on cetrimide agar (0.03 $\mathrm{g} / 100 \mathrm{ml}$; Brown and Lowbury, 1965) and the only two antibiotics to which all the strains were sensitive were carbenicillin and colistin (Table 3). All the isolates were resistant to amoxicillin and cephalexin and all were also resistant to vibriostatic agent 0/129. 


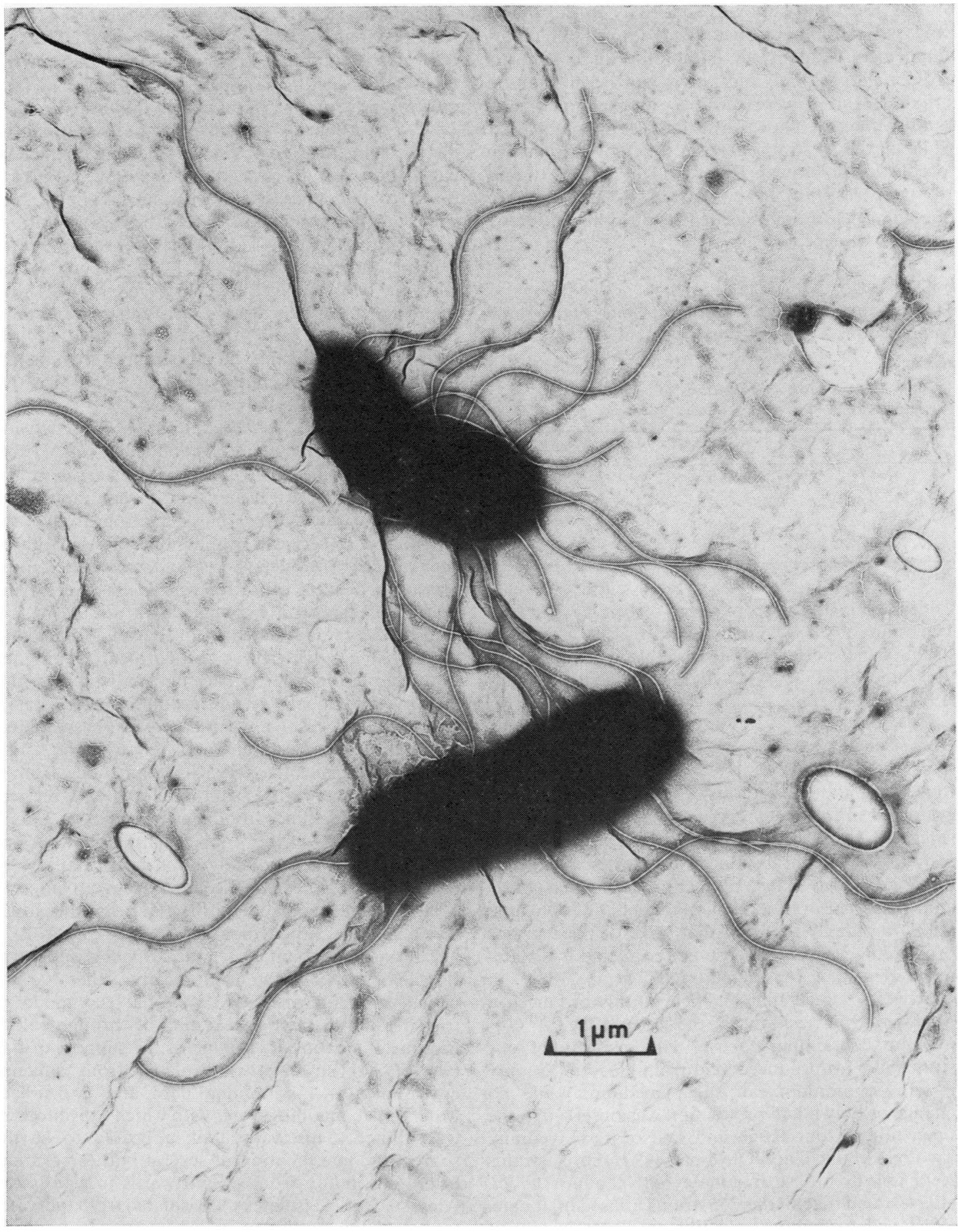

Figure Electron micrograph of strain 2 (CL356/72) showing peritrichous arrangement of flagella. Preparation stained with $1 \%(w / v)$ phosphotungstic acid. 
Strains 1, 2, and 7 showed sensitivity to the widest range of antibiotics including ampicillin, chloramphenicol, kanamycin, streptomycin, co-trimoxazole, nalidixic acid, and polymyxin $\mathbf{B}$; in addition strains 2 and 7 were sensitive to gentamicin and strain 7 to tetracycline. It was interesting to note that while all the 14 strains examined here were sensitive to colistin (polymyxin E) two of the strains (6 and 10) were resistant to polymyxin $B$, although the remaining 12 strains were sensitive to this antibiotic as might be expected.

DNA BASE COMPOSITIONS

The melting temperatures (Tm) and DNA base compositions ( $\%$ GC) are shown in Table 4 . The

Table 4 DNA base compositions of selected strains of A. xylosoxidans

\begin{tabular}{lll}
\hline Strain No. & $\operatorname{Tm}\left({ }^{\circ} \mathrm{C}\right)$ & $\% G C$ \\
\hline 5 & $83 \cdot 2$ & $67 \cdot 5$ \\
6 & $82 \cdot 7$ & $66 \cdot 5$ \\
8 & $83 \cdot 3$ & $67 \cdot 7$ \\
10 & $83 \cdot 3$ & $67 \cdot 7$ \\
NCTC 10807 & $83 \cdot 1$ & $67 \cdot 3$ \\
\hline
\end{tabular}

values are in the narrow range of $66 \cdot 5-67 \cdot 7 \%$ GC. The value of $67.3 \%$ GC for NCTC 10807 , the type strain of the species, is in reasonable agreement with the value of $69 \cdot 2 \%$ GC given by Yabuuchi et al. (1974) for the same strain.

\section{Discussion}

In general the 11 field strains of $A$. xylosoxidans examined in this study agree well in their characteristics with the three strains held in the NCTC (which include the type strain) and with the descriptions of the organism given by Yabuuchi and Ohyama (1971) and Yabuuchi et al. (1974). Yabuuchi and Ohyama (1971) originally reported that none of their strains produced acid from glucose but corrected this statement in a later report (Yabuuchi et al., 1974), in which they stated that all their strains produced a weak-positive reaction in the open tube of O-F medium containing glucose. The majority of our strains (13/14) produced acid from glucose but only in our ammonium salt sugar medium, while no change or only alkali production was observed in the open tube of our Hugh and Leifson O-F medium. Two of Yabuuchi and Ohyama's (1971) seven strains were able to utilise malonate but Yabuuchi $e t$ al. (1974) stated that all their 55 strains utilised malonate. We failed to demonstrate this character in any of our strains.
The five isolates from water and disinfectant solutions represented by strain 10 showed minor differences from each other and differed from the other strains of $A$. xylosoxidans examined in producing acid from mannitol and in failing to grow at $37^{\circ} \mathrm{C}$. Nevertheless, we think that the strain can be included in this taxon since it has peritrichous flagellation, produces acid from xylose, and conforms to the other strains examined in most biochemical characters and in DNA base composition.

Our results in tests of antibiotic sensitivity are in general agreement with those of Yabuuchi and Ohyama (1971) and Yabuuchi et al. (1974)-who found most of their strains resistant to most antibiotics tested-except that, in contrast to the majority of their strains, all our strains were sensitive to carbenicillin and colistin and most were sensitive to ampicillin and to polymyxin $\mathbf{B}$.

$A$. xylosoxidans has been isolated from a wide range of clinical material. Yabuuchi et al. (1974) reported strains isolated from ear discharges, spinal fluid, sputum, brain, urine, skin, throat, stool, pus, respiratory tract, ulcer, burn, peritoneal dialysis, blood, and a cervical lymph node. These authors . cite two cases in which $A$. xylosoxidans seemed to be playing a definite causative role in disease. In the first case, reported by Shigeta et al. (1974), $A$. xylosoxidans was isolated from the spinal fluid of a 9-year-old girl with recurrent purulent meningitis. $\stackrel{\mathbb{D}}{\Omega}$ The strain isolated from the patient was agglutin- $\overrightarrow{\vec{B}}$ ated by the patient's serum in dilution up to $1: 640$. ำ In the second case $A$. xylosoxidans was isolated in pure culture from arterial blood, venous blood, and a biopsy specimen of a cervical lymph node from a 42-year-old man with remittent fever and cervical ? lymph node swelling. In our series strains $1,3,6,7$, 10 , and probably 11 seemed to be harmless and strains $2,4,5$, and 9 were possibly opportunist pathogens. Strain 8 was repeatedly isolated from an infected orbit, and the clinical details suggest that this strain was playing a pathogenic role.

The natural habitat of $A$.xylosoxidans is unknown. Possibly, in common with many other Gram- N negative, non-fermentative bacteria, the mode of transmission in the hospital may be through colon- 0 isation of aqueous environments. In support of this $\mathrm{E}$ two of our strains were isolated from aqueous? environments - a swimming pool and a distilled-c water tank containing water with which a disinfectant $\Phi_{\infty}$ was diluted. This water tank appeared to be the ${ }^{?}$ source of contamination of several bottles of chlor- $\frac{T}{T}$ hexidine solution from several wards in a hospital. $\frac{O}{\mathbb{D}}$ Almost identical isolates were isolated from the water $\stackrel{\odot}{\odot}$ tank and the bottles of chlorhexidine. In addition $\stackrel{\mathbb{Q}}{\Omega}$ to their resistance to the chlorhexidine solution these 
particular isolates were resistant to amoxicillin, cephalexin, chloramphenicol, tetracycline, and nalidixic acid, as were most strains in our series, but they were included among the few strains in our series resistant to ampicillin, and polymyxin B at a concentration of $300 \mathrm{IU} / \mathrm{ml}$.

The classification of Gram-negative, non-fermentative peritrichous flagellate rods is problematical. Yabuuchi and Ohyama (1971) placed this species in the genus Achromobacter because the characters conformed to the definition of that genus given by Breed (1957), Hendrie et al. (1964), and Hugh (1970). Achromobacter Bergey et al. (1923) is considered by many to be an illegitimate name since the original description was inadequate and there is no extant type strain of the type species of the genus $A$. liquefaciens. Recently Hendrie et al. (1974) have formally proposed the rejection of the genus name Achromobacter. Although many of the characters of A. xylosoxidans resemble those of organisms in the genus Alcaligenes the production of acid from glucose and xylose would exclude $A$. xylosoxidans from this genus.

Whatever the future generic position of $A$. xylosoxidans, strains of this species may be readily identified from their homogeneous and distinctive biochemical characteristics.

For easy recognition of $A$. xylosoxidans the salient characters are as follows: Gram-negative rods, motile by peritrichous flagella; aerobic; catalase and oxidase positive; alkaline reaction or no change in Hugh and Leifson's glucose O-F medium; nitrate reduced; tolerate $\mathrm{KCN}$; produce acid from glucose and xylose and sometimes from ethanol in an ammonium salt sugar medium with bromothymol blue indicator.

We are grateful to the Department of Health and Social Security, whose grant for the identification of bacteria using a computer enabled this work to be carried out. Our thanks are also due to all those who sent us strains of $A$. xylosoxidans for identification. We thank A. A. Porter for the electron microscopy.

\section{References}

Anderson, E. S. and Threlfall, E. J. (1974). The characterization of plasmids in the enterobacteria. J. Hyg., 72, 471-487.

Bergey, D. H., Harrison, F. C., Breed, R. S., Hammer, B. W., and Huntoon, F. M. (1923). In Bergey's Manual of Determinative Bacteriology, pp. 132-154. Williams and Wilkins, Baltimore.
Breed, R. S. (1957). Achromobacter Bergey et al, 1923. In Bergey's Manual of Determinative Bacteriology, 7th edition, edited by R. S. Breed, E. G. D. Murray, and N. R. Smith, pp. 300-309. Williams and Wilkins, Baltimore.

Brenner, D. J., Fanning, G. R., Rake, A. V., and Johnson, K. E. (1969). Batch procedure for thermal elution of DNA from hydroxyapatite. Analyt. Biochem., 28, 447-459.

Brown, V. I. and Lowbury, E. J. L. (1965). Use of an improved cetrimide agar medium and other culture methods for Pseudomonas aeruginosa. J. clin. Path., 18, 752-756.

Hendrie, M. S., Hodgkiss, W., and Shewan, J. M. (1964). Considerations on organisms of the AchromobacterAlcaligenes group. Ann. Inst. Pasteur de Lille, 15, 43-59.

Hendrie, M. S., Holding, A. J., and Shewan, J. M. (1974). Emended descriptions of the genus Alcaligenes and of Alcaligenes faecalis and proposal that the generic name Achromobacter be rejected: status of the named species of Alcaligenes and Achromobacter. Int. J. system Bact., 24, 534-550.

Holmes, B., Lapage, S. P., and Malnick, H. (1975). Strains of Pseudomonas putrefaciens from clinical material. J. clin. Path., 28, 149-155.

Hugh, R. (1970). A practical approach to the identification of certain nonfermentative Gram-negative rods encountered in clinical specimens. Publ. Hlth Lab., 28, 168-187.

King, E. O. (1964). The Identification of Unusual Pathogenic Gram-Negative Bacteria. National Communicable Disease Center, Atlanta, Georgia.

Mandel, M., Igambi, L., Bergendahl, J., Dodson, M. L., Jr, and Scheltgen, E. (1970). Correlation of melting temperature and cesium chloride buoyant density of bacterial deoxyribonucleic acid. J. Bact., 101, 333-338.

Marmur, J. (1961). A procedure for the isolation of deoxyribonucleic acid from micro-organisms. J. molec. Biol., 3, 208-218.

Owen, R. J., Hill, L. R., and Lapage, S. P. (1969). Determination of DNA base compositions from melting profiles in dilute buffers. Biopolymers, 7, 503-516.

Shigeta, S., Higa, K., Ikeda, M., and Endo, S. (1974). A purulent meningitis caused by Achromobacter xylosoxidans. Igaku No Ayumi, 88, 336-337. (In Japanese: cited by Yabuuchi et al., 1974.)

Smith, H. R., Humphreys, G. O., Grindley, N. D. F., Grindley, J. N., and Anderson, E. S. (1973). Molecular studies of an $\mathrm{fi}^{+}$plasmid from strains of Salmonella typhimurium. Molec. gen. Genet., 126, 143-151.

Yabuuchi, E. and Ohyama, A. (1971). Achromobacter xylosoxidans $\mathrm{n}$. sp. from human ear discharge. Japan. J. Microbiol., 15, 477-481.

Yabuuchi, E., Yano, I., Goto, S., Tanimura, E., Ito, T., and Ohyama, A. (1974). Description of Achromobacter xylosoxidans Yabuuchi and Ohyama 1971. Int. J. system Bact., 24, 470-477. 